\title{
Lamivudine resistance in naïve chronic hepatitis B patients
}

\section{Tedavi naif kronik hepatit B hastalarında lamuvidin direnci}

Engin Altunkaya

Department of Gastroenterology, Cumhuriyet University Faculty of Medicine, Sivas, Turkey

Corresponding author: Engin Altınkaya, MD, Department of Gastroenterology, Cumhuriyet University Faculty of Medicine, Sivas, Turkey

E-mail: altinkayaengin@gmail.com

Received/Accepted: June 08, 2019 /September 25, 2019

Conflict of interest: There is not a conflict of interest.

\begin{abstract}
Objective: Prevalence of lamivudine resistance in treatmentnaive hepatitis $B$ patients shows variation among populations. The present study aimed to determine the prevalence of lamivudine resistance in treatment-naïve chronic hepatitis B (CHB) patients followed in Turkish population.

Method: The study comprised 71 chronic hepatitis B patients that have never received treatment for chronic hepatitis B infection before (treatmentnaïve). HBV DNA was detected quantitatively by real-time polymerase chain reaction (RT-PCR) method in serum samples collected from the patients. Sequence analysis and reverse hybridization by string method were used to determine Lamivudine motif mutants. Liver biopsy was performed in all patients. Serum samples collected were used to determine HBeAg and anti-HBeAb levels.

Results: Of the 71 patients participated in the study. The mutation was detected in a total of 8 patients, and the prevalence was $11.3 \%(8 / 71)$. The incidence of mutation was $8.3 \%(4 / 48)$ in HBeAg-negative patients, and it was lower than $\mathrm{HBeAg-positive} \mathrm{patients,} \mathrm{in} \mathrm{whom} \mathrm{the} \mathrm{prevalence} \mathrm{was} 17 \%$ $(4 / 23)(p=0.01)$. Comparing the patients with and without mutation in terms of demographic characteristics, ALT levels, HAI and fibrosis scores, no statistically significant difference was determined $(\mathrm{p}=0.29)$.

Conclusions: In the present study, the prevalence of mutation was $11.3 \%$ in treatment-naïve chronic hepatitis B patients. Therefore, determining local prevalence for all populations and planning the treatment accordingly may prevent future complications and thereby enhance the efficacy of treatment. Choosing drugs with low resistance profile and starting treatment considering this resistance.
\end{abstract}

Keywords: Chronic hepatitis B, lamivudine, drug resistance

$$
\text { Engin Altınkaya }
$$

ORCID IDs of the authors: E.A. 0000-0001-6636-7073 
Amaç: Tedavi naif hepatit B hastalarında lamivudin direncinin prevalansı popülasyonlar arasında değişkenlik göstermektedir. Bu çalışma Türk popülasyonunda takip edilen naif kronik hepatit B hastalarında lamivudin direncinin prevalansını belirlemeyi amaçlamıştır.

Materyal ve Metod: Çalışma, daha önce kronik hepatit B enfeksiyonu için hiç tedavi görmemiş 71 kronik hepatit B hastasını (tedavi naif) içermektedir. HBV DNA hastalardan toplanan serum örneklerinde gerçek zamanlı polimeraz zincir reaksiyonu (RT-PCR) metodu ile kantitatif olarak tespit edildi. Lamivudin motif mutantlarını belirlemek için dizi analizi ve dizi metodu ile ters hibridizasyon kullanılmıştır. Tüm hastalara karaciğer biyopsisi yapıldı. Toplanan serum numuneleri HBeAg ve anti-Hbe seviyelerini belirlemek için kullanılmıştır.

Bulgular: Çalışmaya toplam 71 hasta alındı. Toplam 8 hastada mutasyon saptandı ve prevalansı \% 11.3 idi (8/71). HBeAg negatif hastalarda mutasyon prevalans1 \% 8,3 (4/48) idi ve prevalans1 \% 17 olan (4/23) HBeAg pozitif hastalardan düşüktü $(\mathrm{p}=0,01)$. Mutasyon olan ve olmayan hastaların demografik özellikler, ALT düzeyleri, HAI ve fibroz skorları açısından karşılaştırılması sonucunda istatistiksel olarak anlamlı bir fark saptanmadı $(\mathrm{p}=0,29)$.

Sonuç: Bu çalışmada, naif kronik hepatit B hastalarında lamivudin mutasyon prevalansı \% 11.3 saptandı. Bu nedenle, tüm popülasyonlar için lokal lamivudin mutasyon prevalansını belirlemek ve buna göre direnç profili düşük ilaçlar ile tedaviye başlamak ilerde olışabilecek komplikasyonları önleyebilir.

Anahtar sözcükler: Kronik hepatit B, Lamivudin, ilaç direnci

\section{INTRODUCTION}

Worldwide approximately 2 billion people have been infected with hepatitis B virus (HBV) and were seropositive. It is estimated that four hundred million people have chronic HBV infection, of whom approximately $7-30 \%$ has been infected with HBV variants. Lamivudine is the first reverse transcriptase (RT) inhibitor used in the treatment of chronic hepatitis B infection. Lamivudine effectively suppresses viral replication and reduces disease activity. Owing to this effect, it improves the pathology in liver histology that results from hepatitis B and provides deceleration of clinical disease progression. Importance of the polymerase region has been recognized after the use of nucleotide/nucleoside analogs in the treatment of chronic hepatitis B infection. Primary catalytic region of $\mathrm{HBV}$ polymerase is the "reverse transcriptase" enzyme. This enzyme contains A, B, $\mathrm{C}$ and $\mathrm{D}$ domains. Mutations in the tyrosine $(\mathrm{Y})$, methionine (M), aspartate (D), aspartate (D) motif, (YMDD) which forms the rt203-rt206 codons of C domain, is known as the mutations associated with lamivudine resistance (Figure1).

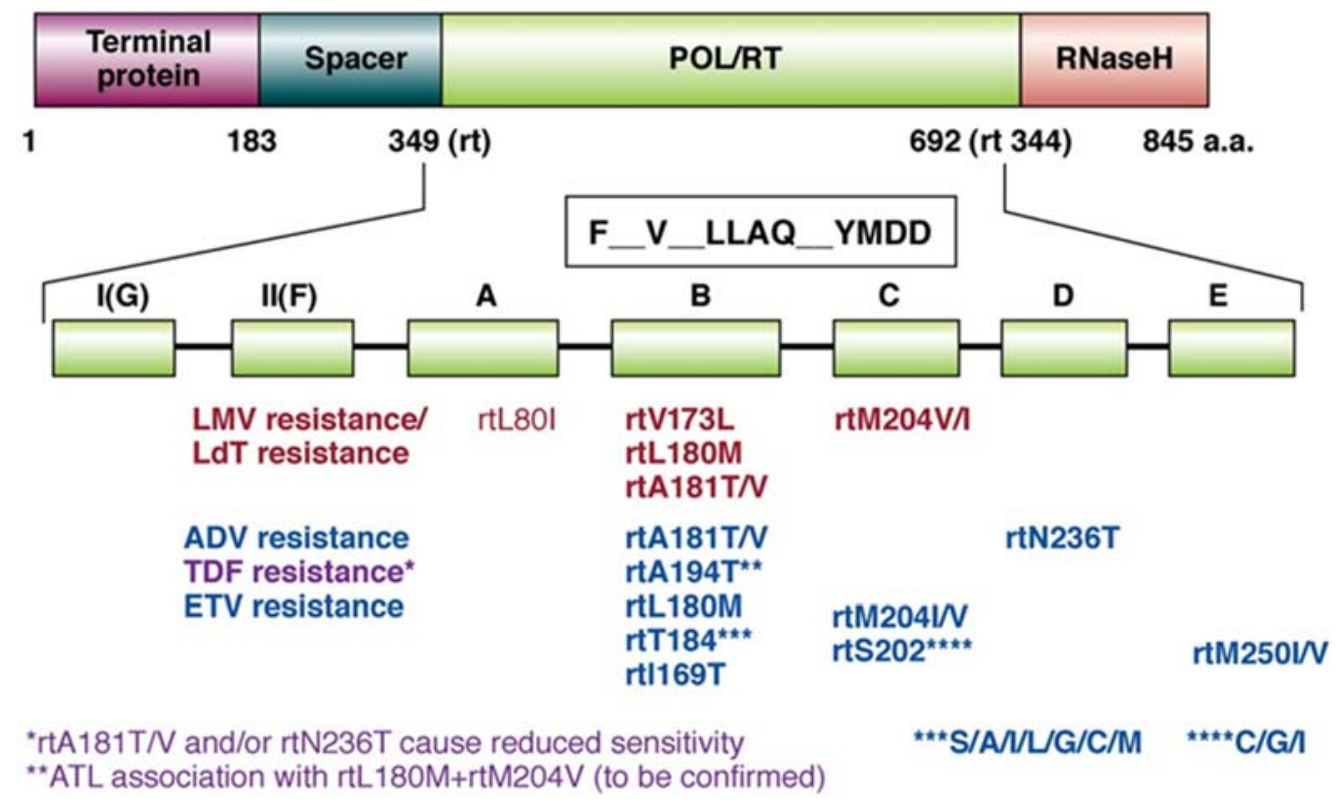

Figure 1: Drug resistance 
Mutations that cause methionine amino acid in $204^{\text {th }}$ position to be replaced by another amino acid also cause the drug to be ineffective ${ }^{1,2,3,4}$. Initially two mutations leading to lamivudine resistance have been reported. It was observed that these mutations are accompanied by L180M mutations in the $180^{\text {th }}$ codon of $\mathrm{B}$ domain of reverse transcriptase, and accordingly, 3 mutations were defined. Group I mutations are togetherness of M204V and L180M mutations; Group II mutations are M204I mutation, and Group III mutations are togetherness of M204I and L180M mutations. LMV resistance progressively increases over the course of treatment. Such that, $14-32 \%$ of the patients gain resistance against drug after one year of treatment and more than $80 \%$ of the patients gains resistance after 48 months. Lamivudine resistance not only develops during treatment but also can be found in treatment-naïve patients as natural genome variance. Prevalence of lamivudine resistance in treatment-naïve chronic hepatitis B patients shows differences among populations. Currently available studies are not adequate to clearly identify its prevalence in Turkish population. The present study aimed to determine the prevalence of YMDD motif mutants in treatment-naïve chronic hepatitis $B$ patients followed in our policlinic as well as in Turkish population together with the studies conducted in other centers.

\section{MATERIAL AND METHODS}

In the present study, the results of 71 patients at the age of 18 years or over, who applied to the gastroenterology polyclinic between 2010 and 2011, have been diagnosed with chronic hepatitis $\mathrm{B}$ based on liver biopsy and biochemical and molecular tests and received no antiviral therapy, were retrospectively evaluated. AST, ALT, Hbe $\mathrm{Ag}$, anti-Hbe, and HBV DNA were studied in serum samples of all patients. Lamivudine resistance profile was studied prior to treatment in treatment-naïve patients in whom HBV DNA was at measurable levels. HAI and fibrosis scores were determined in liver biopsy specimens according to ISHAK scoring system.

\section{Inclusion and exclusion criteria}

Patients that met the following criteria were included in the study

- With positive hepatitis B surface antigen but negative anti-HCV, delta, and antiHIV tests,

- With negative $\mathrm{HBeAg}$, mildly elevated transaminases, and HBV DNA >2000 $\mathrm{U} / \mathrm{I}$,
- With positive $\mathrm{HBeAg}$, almost 2-fold elevated transaminases, and HBV DNA $>20000 \mathrm{U} / \mathrm{I}$.

Patients that received interferon or oral antiviral therapy before, even they have not been receiving currently, were excluded regardless of the duration of treatment that they had received.

\section{HBV DNA viral load test}

After viral DNA isolation, quantitative HBV DNA viral load was determined by Real-Time Polymerase Chain Reaction (RT-PCR) method in serum or plasma samples. During this procedure, Cobas Ampliprep Automated DNA Isolation Device or High Pure Viral Nucleic Acid Kit, which is a manual isolation kit, was used for DNA isolation. During RT-PCR phase, quantitative HBV DNA viral load was determined using Cobas Taqman 48 device (Roche Diagnostics,USA sis.).

\section{Hepatitis $B$ virus drug resistance test}

Following the initial viral DNA isolation performed in serum or plasma samples using sequence analysis method in order to determine the mutations and new mutant strains found in high concentrations in virus population, an adequate amount of PCR product was obtained after twophase outer and nested PCR cycle process, which was performed in thermal cycler. The product was exposed to PCR process in thermal cycler with Forward and Reverse primaries for sequencing (cycle sequencing) specific to Hepatitis B virus. The products formed were analyzed in sequence analyzer. Afterward, mutations in hepatitis B virus codons No 169, 173, 180, 181, 184, 194, 202, 204, 233, 236 and 250 were assessed. Devices used at this phase were GeneAmpPCR 9700 Thermal Cycler Device for PCR and Applied Systems HITACHI 3130 Genetic Analyzer for sequence analysis.

In the second phase, after viral DNA isolation performed by reverse hybridization method (Inno Lipa, BELGIUM) using strip in serum or plasma samples, the DNA obtained was exposed to multiplex PCR (method) process in thermal cycler device to detect minor mutations that have been documented in virus population but could have not been detected by sequence analysis. In the PCR products obtained, codons No 80, 173, 180/181, 204 and 236 of HBV polymerase enzyme was screened by reverse hybridization method and mutations associated with Hepatitis B virus were assessed. The devices used during this procedure included GeneAmpPCR 9700 Thermal Cycler Device for PCR phase and Tecan ProfiBlot 48 
Device for hybridization phase.

\section{Statistical method}

Viral load determined in the patients with and without mutation was presented as mean, median, minimum and maximum. Patients with or without mutation, as well as $\mathrm{HBeAg}$ positive and negative patients were analyzed in terms of viral load and other parameters using student t-test and nonparametric Mann-Whitney U test. A p-value $\leq$ 0.05 was considered statistically significant. Statistical analysis was done using SPSS version 17 software.

\section{RESULTS}

A total of 71 patients that have been diagnosed with chronic hepatitis B and have not received any drug therapy before were enrolled. Of these patients,
$35 \%$ were female $(25 / 71)$ and $65 \%$ were male (46/71). The mean age of the patients was $38 \pm 8.2$ (24-61) years.

\section{Mutasion analysis}

YMDD mutation was detected in 8 of 71 patients $(11.3 \%)$. Of the patients with the mutation, 4 had YIDD (tyrosine, isoleucine, aspartate, aspartate) (rtM204I), and the other four had YVDD (tyrosine, valine, aspartate, aspartate) (rtM204V) mutation. Three of HBeAg-positive patients had YVDD and one had YIDD, whereas three of HBeAg-negative patients had YIDD and one had YVDD mutation. $\mathrm{HBe} \mathrm{Ag}$ and HBV DNA status and mutations of these 8 patients are summarized in table 1 .

Table 1: Types of mutation detected in the patients

\begin{tabular}{|l|l|l|l|}
\hline Gender & HBeAg & HBV DNA & Mutation \\
\hline Male & Positive & $105 \mathrm{X} 10^{3} \mathrm{U} / \mathrm{I}$ & YVDD (rtM204V) \\
\hline Male & Negative & $97 \mathrm{X} 10^{3} \mathrm{U} / \mathrm{I}$ & YIDD (rtM204I) \\
\hline Male & Positive & $122 \mathrm{X} 10^{3} \mathrm{U} / \mathrm{I}$ & YVDD (rtM204V) \\
\hline Male & Negative & $987 \mathrm{X} 10^{2} \mathrm{U} / \mathrm{I}$ & YIDD (rtM204I) \\
\hline Male & Positive & $105 \times 10^{3} \mathrm{U} / \mathrm{I}$ & YIDD (rtM204I) \\
\hline Female & Negative & $78 \times 10^{3} \mathrm{U} / \mathrm{I}$ & YIDD (rtM204I) \\
\hline Female & Positive & $132 \times 10^{3} \mathrm{U} / \mathrm{I}$ & YVDD (rtM204V) \\
\hline Female & Negative & $68 \times 10^{3} \mathrm{U} / \mathrm{I}$ & YVDD (rtM204V) \\
\hline
\end{tabular}

Overall, 32\% (23/71) of the study participants were HBeAg-positive, and 68\% (48/71) were HBeAgnegative. Contrarily, of the patients with the mutation, $50 \%$ were $\mathrm{HBeAg}$-positive ant other $50 \%$ were $\mathrm{HBeAg}$-negative. With regard to overall patient population, the prevalence of mutation was $17 \%(4 / 23)$ in $\mathrm{HBeAg}$-positive patients and $8.3 \%$ (4/48) in HBeAg-negative (anti-HBeAg positive) patients. Comparison of these two groups revealed statistically significant difference $(\mathrm{p}=0.01)$.

The mean HBV DNA viral load was $117 \times 10^{3} \mathrm{U} / \mathrm{I}$ in the patients without mutation and $100 \times 10^{3} \mathrm{U} / \mathrm{I}$ in the patients with the mutation. Comparing the patients with and without mutation in terms of HBV DNA viral load, viral load was slightly higher in the patients without mutation, but the difference was not statistically significant $(\mathrm{p}=0.27$ ).
The mean ALT value was $68 \pm 23 \mathrm{U} / \mathrm{L}$ in the patients without mutation and $65 \pm 27 \mathrm{U} / \mathrm{L}$ in the patients with the mutation. Comparing the patients with and without mutation in terms of ALT values, no statistically significant difference was determined between the groups $(\mathrm{p}=0.4)$

The mean HI in liver biopsy according to Ishak score was 6.9 and mean fibrosis score was 2 in the patients with the mutation, whereas mean HI was 7.1 and mean fibrosis score was 2 in the patients without mutation. There was no statistical difference between the patients with and without mutation in terms of $\mathrm{HI}$ and fibrosis score in the liver biopsy $(\mathrm{p}=0.29)$. 


\section{Virological analysis in the overall patient group}

In $\mathrm{HBeAg}$-positive patients, mean ALT was 98 $\mathrm{U} / \mathrm{L}, \mathrm{HBV}$ DNA was $321 \mathrm{X} 10^{3} \mathrm{U} / \mathrm{I}$, HAI was 7.9 and fibrosis score was 2. In $\mathrm{HBeAg-negative}$ patients, mean ALT was $55 \mathrm{U} / \mathrm{L}, \mathrm{HBV}$ DNA was $170 \mathrm{X} 10^{2} \mathrm{U} / \mathrm{I}$, HAI was 7.1 and fibrosis score was 2.6. Comparing $\mathrm{HBeAg}$-negative and $\mathrm{HBeAg}$ positive patients in terms of these parameters, no statistical difference was determined for HAI and fibrosis score ( $>0.05)$; however, with regard to HBV DNA and ALT value, they were higher in HBeAg-positive patients with statistically significant difference determined between the groups $(\mathrm{p}<0.05)$.

ALT, HAI, fibrosis score and HBV DNA levels according to the $\mathrm{HBeAg}$ positivity and negativity status of the patients and presence or absence of mutation are summarized in table 2 .

Table 2: Parameters of the patients with and without mutation

\begin{tabular}{|c|c|c|c|c|}
\hline Mutation & HAI & Fibrose & ALT & HBV DNA \\
\hline+ & 6,9 & 2,4 & $68,6 \mathrm{U} / \mathrm{L}$ & $117.372 \mathrm{U} / \mathrm{I}$ \\
\hline- & 7,1 & 2,3 & $65,7 \mathrm{U} / \mathrm{L}$ & $100.900 \mathrm{U} / \mathrm{I}$ \\
\hline Total & 6,9 & 2,4 & $68,3 \mathrm{U} / \mathrm{L}$ & $115.516 \mathrm{U} / \mathrm{I}$ \\
\hline \multicolumn{2}{|r|}{ HAI; Histologic activite index, ALT; Alanine aminotransferase } \\
\hline
\end{tabular}

\section{DISCUSSION}

Today, chronic hepatitis B is a significant health problem and one of the most common infectious diseases all over the world. One-third of the world population has been infected with hepatitis B virus, of which $5 \%$ are chronically ill. Approximately one-fourth of these sick chronically patients progress to liver cirrhosis and liver cancer, which are fatal liver diseases. Annually, one million people die due to hepatitis $B$ virus. For these reasons, treatment of hepatitis B virus is essential. Lamivudine is a safe reverse transcriptase inhibitor with good side effect profile and is being used for the treatment of chronic hepatitis B patients for many years. Lamivudine resistance increases as duration of lamivudine exposure are prolonged. Increased drug resistance is a critical problem as it leads to decompensation clinic, even to fatal course. Lamivudine resistance results from amino acid change in YMDD motif due to replacement of leucine by methionine in codon No 180 of domain $\mathrm{B}$ of $\mathrm{HBV}$ (rtL180M) and substitution of methionine by valine or isoleucine in codon No 204 of domain $\mathrm{C}$ in the reverse transcriptase (rt) region of polymerase gene (rtM204V or rtM204I) ${ }^{5-8}$. Recent studies ${ }^{9,10}$ demonstrated that YMDD motif mutants, which are responsible for drug resistance during lamivudine therapy in chronic hepatitis B patients that had not been treated with lamivudine, occurred due to natural genome variance. However, prevalence and significance of natural mutations and how they will be reflected in the clinic and patient treatment remain unclear.

The prevalence rate of YMDD mutation in treatment-naïve chronic hepatitis B patients ranges between $7.5 \%$ and $29.5 \%$ among different geographic regions and populations. It was reported that these mutations occur mostly in genotype $\mathrm{C}$ and mixed genotypes and that types of mutation were rtM204I and rtM204V 9,10,11,12. It has been suggested that such differences in the prevalence of mutations in these studies are associated with the genotype of the population infected with HBV and are usually seen in genotype C. In Turkish population, Tunçbilek et al. ${ }^{13}$ carried out a study to determine YMDD mutation in treatment-naïve patients and determined that all patients were genotype $\mathrm{D}$, prevalence of mutation was $7.1 \%$, and the types mutations were rtM204I and rtM204V. Different from the earlier studies, these outcomes indicated that YMDD mutations in treatment-naïve patients are determined not only in genotype $\mathrm{C}$ but also in the populations with genotype $\mathrm{D}$ predominance such as Turkish population. In the present study, we did not perform genotype analysis as the substantial proportion (over $90 \%$ ) of Turkish population was considered as genotype D. We determined the prevalence of YMDD mutation to be $11.3 \%$ in treatment-naïve chronic hepatitis B patients participated in the study. Although this rate is the same in terms of type of mutation, it is higher than 
the prevalence of mutation found in the study carried out by Tunçbilek et al. ${ }^{13}$. However, since the number of patients was inadequate both in the present and in earlier studies, such studies should be conducted in larger patient populations in multiple centers to assess the prevalence rate of YMDD mutation healthier in treatment-naïve chronic hepatitis B patients in Turkish population.

Earlier studies reported that there is no positive correlation between HBV DNA levels and the incidence of YMDD mutations. In the present study, when the patients with and without mutation were compared in terms of HBV DNA viral load, no statistically significant difference was determined between these two groups although HBV DNA viral load was lower in the patients with mutation versus the patients without mutation $(p=0.27)$. This finding is consistent with the literature supporting that there is no positive correlation between HBV DNA level and YMDD mutations.

Another factor associated with lamivudine resistance mutations in treatment-naïve chronic hepatitis B patients is the positivity or negativity of $\mathrm{HBe}$ antigen. Tunçbilek et al. ${ }^{13}$ determined no relation between $\mathrm{HBeAg}$ and anti-HBeAg status of the patients and prevalence of YMDD mutation and stated that mutation in treatment-naïve patients is independent of these factors. Kobayashi et al. ${ }^{8}$ conducted a study in treatment-naïve patients diagnosed with chronic hepatitis $\mathrm{B}$ and determined high prevalence of YMDD mutation as $29.7 \%$ in HBeAg-positive group. In light of these data, they stated that YMDD mutation is more prevalent in HBe-positive patients. Ye et al. ${ }^{14}$ reported that YMDD mutation is more common in anti-HBeAbpositive patients. In the present study, analyzing the prevalence rate of mutation of $11.3 \%$ in overall patient group, whilst the prevalence of mutation was $17 \%$ in $\mathrm{HBeAg}$-positive patients, it was determined $8.1 \%$ in anti $\mathrm{HBeAb}$-positive patients. The results of the present study appear to support the literature, which defend that the prevalence rate of YMDD mutation is higher in HBe-positive patients.

HAI and fibrosis scores obtained by pathological examination of liver biopsy specimens of the patients were compared in the patients with and without mutation and no significant difference was determined between the two groups in terms of these data $(p=0.29)$. These results support that HAI and fibrosis score have no relation with mutation.

With regard to the ALT values of the patients, no statistically significant difference was found between the groups with and without mutation $(\mathrm{p}=0.4)$. However, comparing ALT values between HBeAg-positive and negative patients, ALT values were higher in HBeAg-positive patients with statistically significant difference $(\mathrm{p}<0.05)$. Based on the results of the present study, no relation was determined between ALT values and prevalence of mutation.

In conclusion, although Lamivudine is a safe drug with good side effect profile and is being used in the treatment of chronic hepatitis B patients for many years, increased drug resistance in line with lamivudine exposure and subsequent clinical outcomes remain as critical problems. Besides, development of such resistance in treatment-naïve patients appears as a separate problem. Prevalence of this mutation in treatment-naïve patients shows variation among populations. Checking resistance status prior to the lamivudine therapy in the populations where this prevalence is high may prevent future complications. Therefore, determining local prevalence rates of resistance for all populations and planning treatment accordingly in chronic hepatitis B patients may prevent future complications and enhance efficacy of treatment. Clinical significance of YMDD mutations in treatment-naïve patients has not been clarified yet and further studies in larger patient populations are needed for this. This mutation in naïve patients should be considered in choosing drugs with low resistance risk particularly in the populations where this mutation is prevalent, and accordingly, the dugs with low cross-resistance risk should be preferred.

\section{REFERENCES}

1. Heo J, Cho M, Kim HH, Shin YM, Jang HJ, Park HK, Kim CM, Kim GH, Kang DH, Song GA, Yang US. Detection of YMDD motif mutants by oligonucleotide chips in lamivudine-untreated patients with chronic hepatitis B virus infection. J Korean Med Sci. 2004 ;19:541-5.

2. Lok ASF, McMahon BJ. Chronic hepatitis B. Hepatology 2007 feb;45; 507-539.

3. Tacke F, Gehrke C, Luedde T, Heim A, Manns MP, Trautwein C. Basal core promoter and precore mutations in the hepatitis B virus genome enhance replication efficacy of Lamivudine-resistant mutants. J Virol. 2004 Aug;78(16):8524-35.

4. Tassopoulos NC, Volpes R, Pastore G, Heathcote J, Buti M, Goldin RD, Hawley S, Barber $\mathrm{J}$, Condreay L, Gray DF. Efficacy of lamivudine in patients with hepatitis $B$ e antigennegative/hepatitis B virus DNA-positive (precore mutant) chronic hepatitis B. Lamivudine Precore 
Mutant Study Group. Hepatology. 1999 Mar;29(3):889-96.

5. Chayama K, Suzuki Y, Kobayashi M, Tsubota A, Hashimoto M, Miyano Y, et al. Emergence and takeover of YMDD motif mutant hepatitis B virus during long-term lamivudine therapy and retakeover by wild type after cessation of therapy. Hepatology 1998: 1711-27.

6. Allen MI, Gauthier J, DesLauriers M, Bourne EJ, Carrick KM, Baldanti F, et al. Tw o sensitive PCR-based methods for detection of hepatitis B virus variants associated with reduced susceptibility to lamivudine. J Clin Microbiol 1999 oct: 3338 - 47., 37.

7. Kirishima T, Okanoue T, Daimon Y, Itoh Y, Nakamura H, Morita A, et al. Detection of YMDD mutant using a novel sensitive method in chronic liver disease type $\mathrm{B}$ patients before and during lamivudine treatment. J Hepatol 2002; 37 :25965.

8. Kobayashi S, Ide T, Sata M. Detection of YMDD motif mutations in some lamivudine-untreated asymptomatic hepatitis B virus carriers. J Hepatol 2001; 34: 584-6.

9. Kirishima T, Okanoue T, Daimon Y, Itoh Y, Nakamura H, Morita A, Toyama T, Minami M. Detection of YMDD mutant using a novel sensitive method in chronic liver disease type B patients before and during lamivudine treatment. J Hepatol. 2002; 37: 259-265.
10. Matsuda M, Suzuki F, Suzuki Y, Tsubota A, Akuta N, Hosaka T, Someya T, Kobayashi M, Saitoh S, Arase Y, et al. YMDD mutants in patients with chronic hepatitis B before treatment are not selected by lamivudine. J Med Virol. 2004; 74: 361-366.

11. Huang ZM, Huang QW, Qin YQ, et al. Clinical characteristics and distribution of hepatitis B virus genotypes in Guangxi Zhuang population. World J Gastroenterol 2005; 11; 6525-9.

12. Heo J, Cho M, Kim HH, Shin YM, Jang HJ, Park HK, Kim CM, Kim GH, Kang DH, Song GA, Yang US. Detection of YMDD motif mutants by oligonucleotide chips in lamivudine-untreated patients with chronic hepatitis B virus infection. J Korean Med Sci. 2004; 19: 541-45.

13. Tunçbilek S, Köse S, Elaldi A, Akman S. Lamivudine resistance in untreated chronic hepatitis B patients in Turkey. Turk J Gastroenterol. 2008; 19; 99-103.

14. Ye XG, Wang RL, Guo HB. Detection and analysis of YMDD mutate genes in patients of chronic hepatitis B before being treated. Zhonghua Jianyan Yixue Zazhi 2002; 25; 248-51. 